Int. J. Dev. Biol. 53: 1529-1540 (2009)

doi: $10.1387 / \mathrm{ijdb} .072413 \mathrm{md}$

\title{
Epiblast-derived stem cells in embryonic and adult tissues
}

\author{
MARIA P. DE-MIGUEL*,1, FRANCISCO ARNALICH-MONTIEL ${ }^{1}$, PILAR LOPEZ-IGLESIAS ${ }^{1}$, \\ ALEJANDRO BLAZQUEZ-MARTINEZ ${ }^{1}$ and MANUEL NISTAL ${ }^{2}$ \\ ${ }^{1}$ Cell Engineering Laboratory and ${ }^{2}$ Pathology Department, La Paz Hospital, Madrid, Spain
}

\begin{abstract}
Pluripotent cells can be isolated from the mammalian inner cell mass (ICM) of the embryo at the blastocyst stage, and maintained in culture as undifferentiated, embryonic stem cells (ES). These cells are an important model of mammalian development in vitro and are the focus of a great deal of research for their use in Cell Therapy. In vivo, shortly after the blastocyst stage, the ICM segregates into two layers: the hypoblast which will give rise to the yolk sac, and the epiblast. Epiblast stem cells, like ES cells, are pluripotent. The epiblast will differentiate very early into germ cell progenitors, the primordial germ cells (PGC). PGCs can give rise to embryonal carcinoma cells, the pluripotent stem cells of testicular tumors. During normal embryo development, PGCs migrate into the aorta-gonad-mesonephros region (AGM). Interestingly, this region also harbors the first wave of embryonic hematopoiesis. Subsequent waves of hematopoiesis involve AGM-hematopoietic stem cell (HSC) colonization of the fetal liver, thymus, spleen and ultimately, for adult hematopoiesis, the bone marrow (BM). The BM is also source of mesenchymal stem cells (MSCs). It is accepted that the AGM region cells give rise to the mesothelial cells which are the embryonic precursors of the HSC and MSC of the BM. Recent identification of a subpopulation of cells with markers typical of PGCs in the adult BM, which are capable of differentiating into HSCs, suggests that HSCs originate from a common precursor of PGCs and HSCs derived from the epiblast. Several groups have described the presence of stem cells with the same markers in epidermis, bronchial epithelium, pancreas, retina, hair follicle, heart and dental pulp among, other organs. This presence supports the hypothesis that during early development, epiblast/germ line-derived cells are deposited in various organs which persist into adulthood. The question remains whether these pluripotent stem cells are only developmental remnants or if they continuously contribute to the renewal of tissues, and thus can be reactivated for tissue regeneration without the need for stem cell transplantation for human cell therapies.
\end{abstract}

KEY WORDS: cell therapy, primordial germ cell, hematopoietic stem cell, mesenchymal stem cell

\section{Embryonic origin of the epiblast}

After fertilization, the single-cell zygote divides four times originating the 16-cell morula. The morula consists of a small group of internal cells surrounded by a larger group of external cells. Most of the descendants of the external cells become the trophoblast (trophectoderm) cells, which produce no embryonic structures, but instead the embryonic portion of the placenta, the chorion. The embryo is derived from the descendants of the inner cells of the 16 cell-stage morula. These cells generate the inner cell mass (ICM), which will give rise to the embryo and its associated yolk sac, allantois and amnion. Once the commitment to become trophoblast or inner cell mass is made, different genes are expressed by the cells of these two regions.
The first segregation of cells within the inner cell mass forms two layers: the lower layer, the hypoblast which will give rise to the yolk sac, and the remaining inner cell mass tissue above it, the epiblast (Fig. 1). Epiblast stem cells (EpiSC) are pluripotent cells that will give rise to cells of the three germ layers, ectoderm, mesoderm and endoderm. Stage-specific embryonic antigens

\footnotetext{
Abbreviations used in this paper: AGM, aorta-gonad-mesonephros; BMP, bone morphogenetic protein; EG, embryonic germ cell; EpiSC, epiblast-derived stem cell, ES, embryonic stem cell; HSC, hematopoietic stem cell; ICM, inner cell mass; LIF, leukemia inhibitory factor; MAPC, multipotent adult progenitor cell; MSC, mesenchymal stem cell; PGC, primordial germ cell; PSC, pluripotent stem cell; SSEA, stage-specific embryonic antigen; VSEL, very small embryonic-like.
}

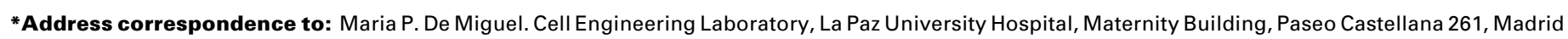
28046 Spain. Tel: +34-91-207-1458. Fax: +34-91-727-7050. e-mail: maria.demiguel@uam.es 
(SSEA) have historically been used as markers of pluripotency. Epiblast cells express SSEA-1 (mice) and SSEA-3/4 (human). Distribution of SSEA-1 has been studied in postimplantation murine embryos, fetuses, and adult mice by immunohistochemical techniques. SSEA 1 is first detected in late eight-cell mouse embryos. It is expressed in the embryonic ectoderm, the visceral endoderm and trophoblast in early postimplantation embryos (Muramatsu and Muramatsu., 2004). In the inner cell mass, SSEA-1 expression is weak at an early stage and becomes greater at a later stage (Muramatsu and Muramatsu, 2004). During subsequent development, SSEA-1 becomes localized to portions of the brain and primordial germ cells. In addition, some sites of the urogenital anlagen are SSEA-1 positive. Interestingly, human embryonic cells express SSEA-3 and SSEA-4 instead of SSEA-1 (Henderson et al., 2002). In addition, epiblast cells express Oct-4 and Nanog. Oct-4 is an embryonic transcription factor that plays a determining role in the specification of mouse pluripotent stem cells (PSC) in the inner cell mass of the blastocyst, and mouse embryos deficient in Oct-4are unable to form mature blastocysts (Hay etal., 2004) and die around the time of implantation (Boiani \& Scholer, 2005). Oct4 becomes downregulated during development as cells are derived to one specific cell line.

\section{ICM and ES cells}

Pluripotent cells can be isolated from the mouse and human inner cell mass (ICM) of the blastocyst and maintained in culture as self-renewing, undifferentiated, embryonic stem cells (ES cells, Evans \& Kaufamn, 1981). These cells are an important model of mammalian development in vitro and are the focus of a great deal of research aimed at generating differentiated cell types for Cell Therapy. The markers that have been used to characterize human ES are carbohydrate epitopes on proteoglycans or sphingolipids, such as stage-specific embryonic antigen (SSEA)-3 and -4. The expression of SSEA-3 and -4 is tightly regulated during preimplantation development and on ES cells. Using inhibitors of sphingolipid and glycosphingolipid (GSL) biosynthesis to block the generation of SSEA-3 and -4 in hES showed that depletion of these antigens and their precursors had no effect on their differentiation in vitro or in teratoma formation. These experiments demonstrated that the GSLs recognized as SSEA-3 and -4 do not play critical functional roles in maintaining the pluripotency of hESs, but instead suggested roles for this class of molecules during cellular differentiation (Brimble et al., 2007).

Recently, in an elegant review, Thomson (Zwaka and Thomson,
2005), pointed out that it is remarkable that permanent pluripotent embryonic stem cell lines can be derived from preimplantation embryos at all, because, in vivo, pluripotent cells of the early mammalian embryo proliferate only briefly before becoming cells with a more restricted development potential. It had been previously suggested that they be called "embryo-derived stem cells", a more precise term that would distinguish between these new pluripotent cell lines and cells within the embryo (Rossant and Papaioannou, 1984).

Although ES cell lines are generally derived from the culture of the ICM, some experiments suggest that ES cells more closely resemble cells from the epiblast (primitive ectoderm). For example, isolated mouse epiblast gives rise to ES cell lines at a higher frequency than does isolated ICM. Moreover, the culture of epiblast allows the isolation of ES cell lines from mouse strains that have been previously refractory to ES cells isolation (Zwaka and Thomson, 2005; Tesar et al., 2007). However, although these experiments suggest that ES cells are more closely related to epiblast than to ICM, they do not reveal whether ES cells more closely resemble epiblast or a cell derived from it in vitro (Zwaka and Thomson, 2005). The expression of Oct-4 is maintained in only a small proportion of derived ES cells (Buehr and Smith, 2003), which also suggests that only a minority of epiblast cells can transit to a new stable, proliferative pluripotent state, and, subsequently, be expanded as ES cells. These results could be due to an inherent heterogeneity of the primitive ectodermal cell population. In fact, recent data indicate that even the earliest ICM is heterogeneous and consists of a mixture of cells that express either Oct-4 or Gata6(Rossant etal., 2003). Recently, two papers have come to strengthen the hypothesis that human ES more closely resemble epiblast cells (EpiSC) than ICM-derived mouse 
ES cells (Tesar et al., 2007; Brons et al., 2007). First, the pattern of gene expression is more similar between mouse EpiSC and human ES than between mouse and human ES. Second, human ES cells and mouse EpiSC depend on the activin/Nodal signaling pathway to maintain their pluripotent status, whereas mouse ES cells rely on leukemia inhibitory factor (LIF) and bone morphogenetic protein (BMP), as the signaling pathway maintaining pluripotency. Third, mouse EpiSC can not give rise to germ-line transmitting chimeras, as mouse ES do (the germline chimerism of human ES cells is of course untestable). And fourth, epigenetic regulation and stability of human ES cells and mouse EpiSC is more similar between them than to mouse ES (Tesar et al., 2007; Brons et al., 2007). In a recent paper (Chou et al., 2008), new cell lines named FAB-SCs were derived from mouse ICM, by culturing ICM in a cocktail of GF media previously used for EpiSC derivation. FABSCs are different both molecular and functionally from ES and EpiSCs. They maintain pluripotency markers such as Oc-t4, Nanog and Sox2, but fail to form embryoid bodies in vitro, teratoma in vivo, or contribute to chimeras when injected into blastocyst. Interestingly, these pluripotency restrictions can be reverted by in vitro exposition to LIF and BMP4.

The epiblast will differentiate very early into germ cell progenitors (Fig. 1). Shortly before the epiblast is about to give rise to all three germ layers (ectoderm, mesoderm, and endoderm), the first morphologically identifiable precursors of PGC in mice become specified at 6.0 to 6.5 days post coitum (dpc) in the proximal part of the epiblast (McLaren, 2003). Thus, precursors of PGC are the first population of stem cells that is specified in the embryo at the beginning of gastrulation. PGC in mice subsequently move for a short period of time first to the basis of the allantois, which is located in the extraembryonic mesoderm and then migrate into the embryo proper toward the genital ridges (see below), where they will undergo developmental differentiation to oocytes or spermatocytes respectively (Molyneaux and Wylie, 2004).

There are several molecular markers that distinguish early germ cells from other pluripotent cells of the early embryo. One marker, tissue-non-specific alkaline phosphatase (TNAP), is strongly expressed by early germ cells and by ES cells, but is weakly expressed by the epiblast and other surrounding embryonic cells (Ginsburg et al., 1990). Two new markers for early germ cells, Fragilis (Ifitm3) and Dppa3 (also know as Stella or PGC ), have recently been identified, which allow the better separation of early germ cell precursors from their differentiated neighboring cells (Saitou et al., 2002). Several recent reports describing the differentiation of mouse ES cells into cells that express markers of mature male and female germ cells (Hubner et al., 2003; Geijsen et al., 2004) are important for our understanding of the origin of ES cells. In each of these reports, germ cell markers were expressed by ES cells themselves, including those, such as Dppa3, which help distinguish germ cells from primitive ectoderm. Only the expression of more mature germ cell markers (such as mouse vasa homolog, $M v$ h) enabled in vitro-derived germ cells to be distinguished from ES cells themselves. In one study that examined the differentiation of human ES cells into germ cells (Clark et al., 2004), the expression of each of eight genes characteristic of early germ cells was detected in human ES cells, but the expression of each of six genes that are characteristic of later germ cells was not detected. Using immunocytochemistry, it was also shown that most individual human ES cells in a popula- tion express the early germ cell markers Stellarelated (StellaR) and deleted in azoospermia-like (Daz), indicating that a minor subset of randomly differentiating cells in a mixed population is not responsible for the expression of germ markers in ES cell cultures. Importantly, it was also shown that at least one germ cellspecific gene, Dazl, was expressed by human ES cells but not by human ICM (Clark et al., 2004). The existing gene expression data are consistent with the idea that the closest in vivo equivalent to ES cells is not the ICM or even the epiblast, but an early germ cell (Zwaka and Thomson, 2005).

Some of the properties of ES cells, however, suggest that they are not merely the equivalent of early germ cells. For example, the earliest PGC do not self-renew for prolonged periods of time, but instead follow a series of differentiation steps, beginning with germ cell migration and ending in the highly morphological specialization of sperm or egg (Wylie, 1999). Also, although ES cells can differentiate into more mature germ cells in vitro, they do so relatively inefficiently. In addition, isolated PGCs have never been demonstrated to contribute to chimeras when injected into blastocysts, so an exact equivalence to ES cells is unlikely (Zwaka and Thomson, 2005).

\section{From ICM to AGM}

Clonal analysis of the lineage potency of epiblast cells revealed that some cells in the proximal epiblast of the pre-to-early streak stage embryo can give rise to SSEA and TNAP-expressing cells that colonize the allantoic mesoderm and the hindgut endoderm. The location of PGC precursors in the proximal epiblast suggests that only epiblast cells in this region of the early gastrula may possess germ-line potency. However, cells that may contribute descendants to the PGC population are not localized specifically to any area in the proximal epiblast. Oct-4 expression is widely localized in the epiblast of the early gastrula and shows no regionalization to the proximal epiblast (Pesce et al., 1998).

The lack of a pre-determined population of PGC progenitors implies that germ-cell formation is unlikely to be restricted to subsets of epiblast cells. This idea has been elegantly verified by a series of experiments testing the ability of epiblast cells that are localized outside the proximal epiblast to form PGCs. Distal epiblast cells that normally display a neuroectodermal fate transplanted to the proximal region of the epiblast were able to differentiate into cells showing the typical PGC pattern of TNAP activity (Quinlan et al., 1995). In the reciprocal transplantation, proximal epiblast colonized the host neural tissue but did not form PGC-like cells after grafting to the distal epiblast (Tam \& Zhou, 1996; Tsang et al., 2001). These results suggest that cells in the distal and the proximal epiblast are equally competent to form PGCs provided they are placed in an environment that is appropriate for germ cell specification. This raises the intriguing possibility that PGC formation is subject to local environmental influences unique to the proximal epiblast (Tsang et al., 2001). However, since these are necessarily short-term experiments, evidence is lacking that such cells are actually able to give rise to functional mature gametes. More importantly, since there is a very high degree of cell mixing in the epiblast from early postimplantation, descendants of all its founder cells are likely to be present throughout the tissue, including its proximal and distal extremities. Hence, the possibility that only a subset of epiblast 

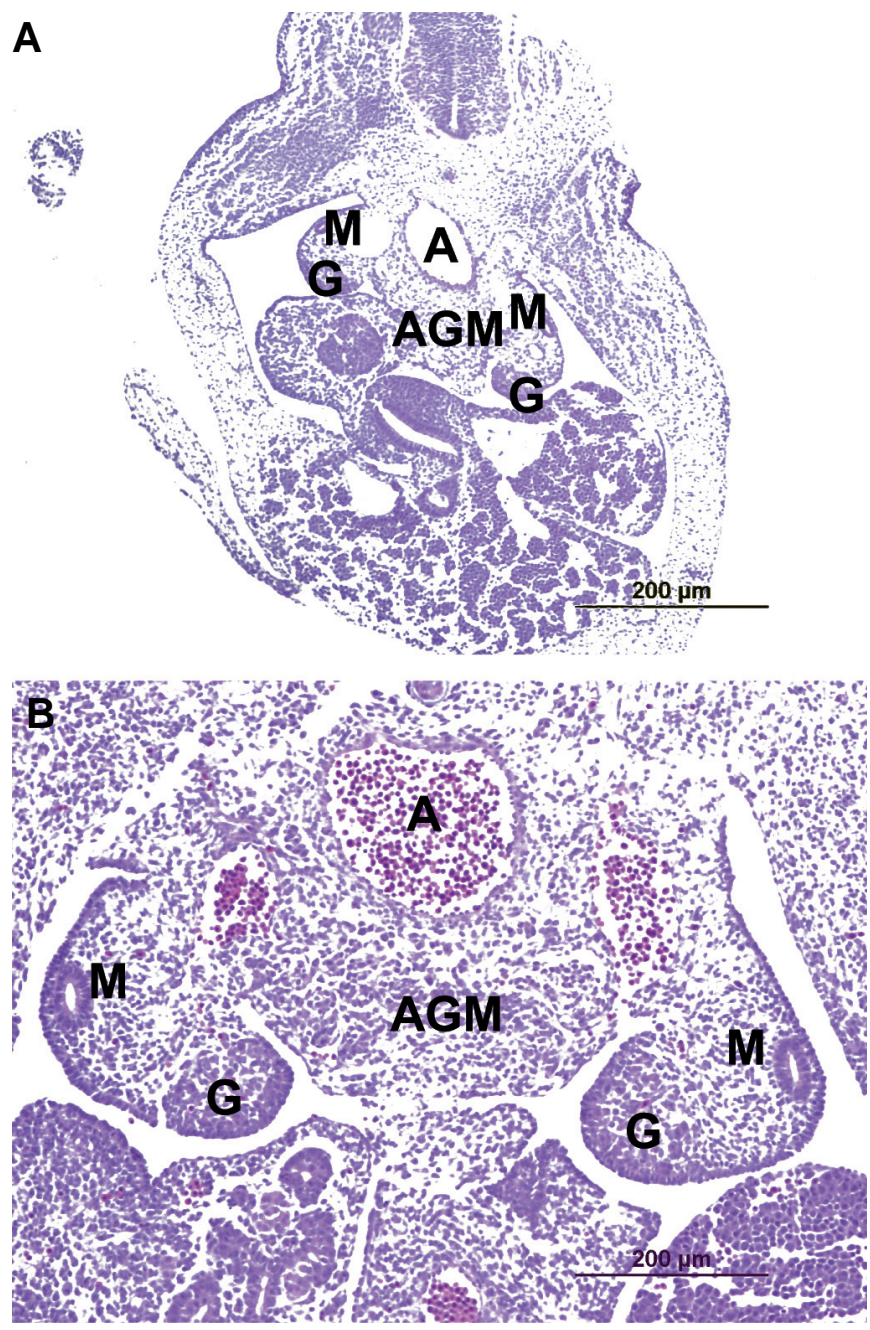

Fig. 2. AGM region in mouse embryos. Mouse embryonic transversal sections at $10.5 \mathrm{dpc}(\mathbf{A})$ and $11.5 \mathrm{dpc}(\mathbf{B})$ at the level of the AGM region. $A$, aorta; $G$, gonad; $M$, mesonephros.

founder clones contain cells that are competent to be induced to form germ cells cannot be discounted at present. Interestingly, descendants of these proximal epiblast cells do not only contribute to the presumptive PGCs but also to other somatic tissues such as the extraembryonic mesoderm.

PGC are the founder cell population of the gametes. During gastrulation, the PGCs that originate from the posterior epiblast ingress though the posterior primitive streak together with the allantoic, intermediate and lateral plate mesoderm (Lawson et al., 1991; Tam and Zhou, 1996; Kinder et al., 1999). In the mouse (McLaren, 2003), they arise early in embryogenesis, first becoming visible in the extraembryonic mesoderm, posterior to the primitive streak, at 6-6.5dpc in mice (Molyneaux \& Wylie, 2004), and can be identified by expression of tissue non-specific alkaline phosphatase (TNAP) activity. Recently, Blimp1 (B -lymphocyteinduced maturation protein 1, also known as Prdm1) a potent transcriptional regulator, has been identified as a key factor for the specification of the germ cell lineage. Blimp1 positive cells at the early stage of $6.25 \mathrm{dpc}$ constitute the lineage restricted PGC precursors. Blimp1 is essential for repressing nearly all the genes normally down-regulated in PGCs. They also express SSEA-1 and Mvh on the surface (Toyooka et al., 2000) and intracellular Oct-4, Stella, Fragilis, Smad1, Nobox and Hdac68(Yabuta et al., 2006).

Afterwards they are incorporated into the epithelium of the hindgut, from which they start to move at day $9.5 \mathrm{dpc}$ first into the dorsal mesentery $(10.5 \mathrm{dpc})$. The mesoderm of the embryo gives rise to an anterior lateral region termed the para-aortasplanchnopleura, which later contributes to the future aorta, gonads and mesonephros (hence, it is termed the AGM region). PGCs migrate from the hindgut, reaching the AGM region at 10.5 dpc (Fig. 2) then into the genital ridges that lie on the dorsal body wall (11.5 dpc). During their migration, primordial germ cells express the SSEA-1 antigen and TNAP on their cell surfaces. These cells can be isolated and cultured for up to a week, maintaining their phenotype (De Miguel \& Donovan, 2000).

\section{From AGM to PGCs, EC and EG cells}

As stated above, at the early-somite stage, PGCs congregate in the endoderm of the prospective hindgut of the embryo. Subsequently, PGCs are relocated from the ventral to the dorsal aspect of the gut, and over the next 3-4 days, migrate from the hindgut endoderm through the mesentery migrating through the AGM region so they can later colonize the urogenital ridges. At that time, around $12.5 \mathrm{dpc}$ in the mouse, the gonads start to show morphological differences between sexes (De Miguel et al., 2000; Donovan \& De Miguel, 2005). During this migration PGCs erase imprints by demethylation (see below) and then re-establish them depending on their $\mathrm{XX}$ or $\mathrm{XY}$ chromosome content.

$P G C s$ that are found outside the genital ridge after $13.5 \mathrm{dpc}$ do not seem able to re-activate the X-chromosome and display only one active X-chromosome (Tsang et al., 2001). Some of these ectopic germ cells, located in the mesonephros and adrenal glands (Francavilla and Zamboni, 1985), will proceed to meiosis at about 16.5-17.5 dpc despite the absence of the re-activation of the X-chromosome (Tam and Zhou unpublished, in Tsang et al., 2001). These ectopic germ cells, however, will not form functional germ cells and are thought to degenerate postnatally (Upadhyay and Zamboni, 1982; McLaren, 2003).

However, recent publications have demonstrated the presence of cells able to give rise to pluripotent ES-like cells in postnatal murine testes (Kanatsu-Shinohara et al., 2004; Guan et al., 2006), and to oocytes both in murine bone marrow (Johnson et al., 2005) and porcine fetal skin (Dyce et al., 2006) as well as the presence of cells able to give rise to spermatogonia in bone marrow (BM) (Nayernia et al., 2006).

Historically, it has been described that PGCs can give rise to two types of pluripotent stem cells. In vivo, PGCs can give rise to embryonal carcinoma (EC) cells, the pluripotent stem cells of testicular tumors (Donovan \& De Miguel, 2003). Cultured PGCs exposed to a specific cocktail of growth factors give rise to embryonic germ (EG) cells, pluripotent stem cells that can contribute to all lineages of chimeric embryos including the germline (Matsui et al., 1992; Resnick et al., 1992). The conversion of PGCs into pluripotent stem cells is a remarkably similar process to nuclear reprogramming in which a somatic nucleus is reprogrammed in the egg cytoplasm (Donovan \& De Miguel, 2003). Both EC and EG cells, like ES cells, share the specific markers 
SSEAs, Oct-4 and TNAP (De Miguel \& Donovan, 2000).

In fact, the derivation of ES cells was based on studies of teratocarcinoma cells. The transplantation of genital ridges or of egg-cylinder-stage embryos into ectopic sites, such as under the kidney capsule of adult mice, gave rise to teratocarcinomas at a high frequency in strains that did not spontaneously produce these tumors (Stevens, 1970). The stem cell of these tumors is the embryonal carcinoma cell, the EC cell, which can be serially transplanted between adult mice (Solter et al., 1981). If the EC compartment disappears, the resulting tumor develops as a benign teratoma. Indeed, EC cells injected into mouse blastocysts can contribute to either the normal tissues of the resulting chimera (Brinster, 1974) or in some cases, to tumors (Rossant and McBurney, 1982).

EG have been derived from pre- and postmigratory as well as from migratory PGC in both mice and humans and are pluripotent (Matsui etal., 1992; Shamblott et al., 1998). That is, EG in contrast to $P G C$ fully contribute to blastocyst complementation giving rise in the developing embryo to all somatic lineages and germ cells. To explain this phenomenon at the molecular level, it is known that the pluripotency of PGC nuclei depends on the methylation status of genomic imprinted genes (e.g., H19, Igf-2, Igf-2R, Snrpn; Mann, 2001; Yamazaki et al., 2003). Until 9.5 dpc, PGC display a somatic imprint (paternal and maternal pattern of methylation) of H19, Igf-2, Igf-2Rand Snrpnt, which is crucial to maintaining their pluripotency. This imprint, however, is erased by demethylation, during the migration of PGCs towards the genital ridges at 10.5 $\mathrm{dpc}$ (Lee et al., 2002). The erasing of the methylation (imprint) in early PGC could be envisioned as one of the mechanisms that shuts down PGC developmental pluripotency and makes these cells resistant to potential parthenogenesis or formation of teratomas (Oosterhuis and Looijenga, 2005). A proper somatic imprint is subsequently reestablished later in sperm and oocytes, so that a fertilized egg expresses a developmentally proper somatic imprint of these crucial genes. That PGC-derived EG cells are pluripotent demonstrates that the re-establishment of a proper somatic imprint is possible.

Mouse EG cell lines are remarkably similar to mouse ES cell lines (Donovan and De Miguel, 2003). Since during germ cell migration and maturation the somatic status of imprinted genes is progressively erased (Yamazaki et al., 2003), EG cells isolated at various stages of migration retain some of these differences, such as the reduced methylation of many imprinted genes, including H19 and Snrpn. The analysis of mouse PGCs at $10.5 \mathrm{dpc}$ suggests that methylation erasure has already begun by this time (Yamazaki et al., 2003). This study showed that imprinted genes exhibit imprinted (somatic) expression patterns in $9.5 \mathrm{dpc}$ PGCs, but by $10.5 \mathrm{dpc}$, they have switched to a bi-allelic mode of expression (Yamazaki et al., 2003). Since the genes expressed in ES cells exhibit somatic imprinting status, these data suggest that if ES cells are derived from germ cells, this derivation must occur before $9.5 \mathrm{dpc}$ in the mouse.

Similar to PGC, other epiblast derived stem cells deposited in the developing tissues undergo erasure of their somatic imprint.

\section{Embryonic hematopoiesis}

Mouse ontogeny (d.p.c.)

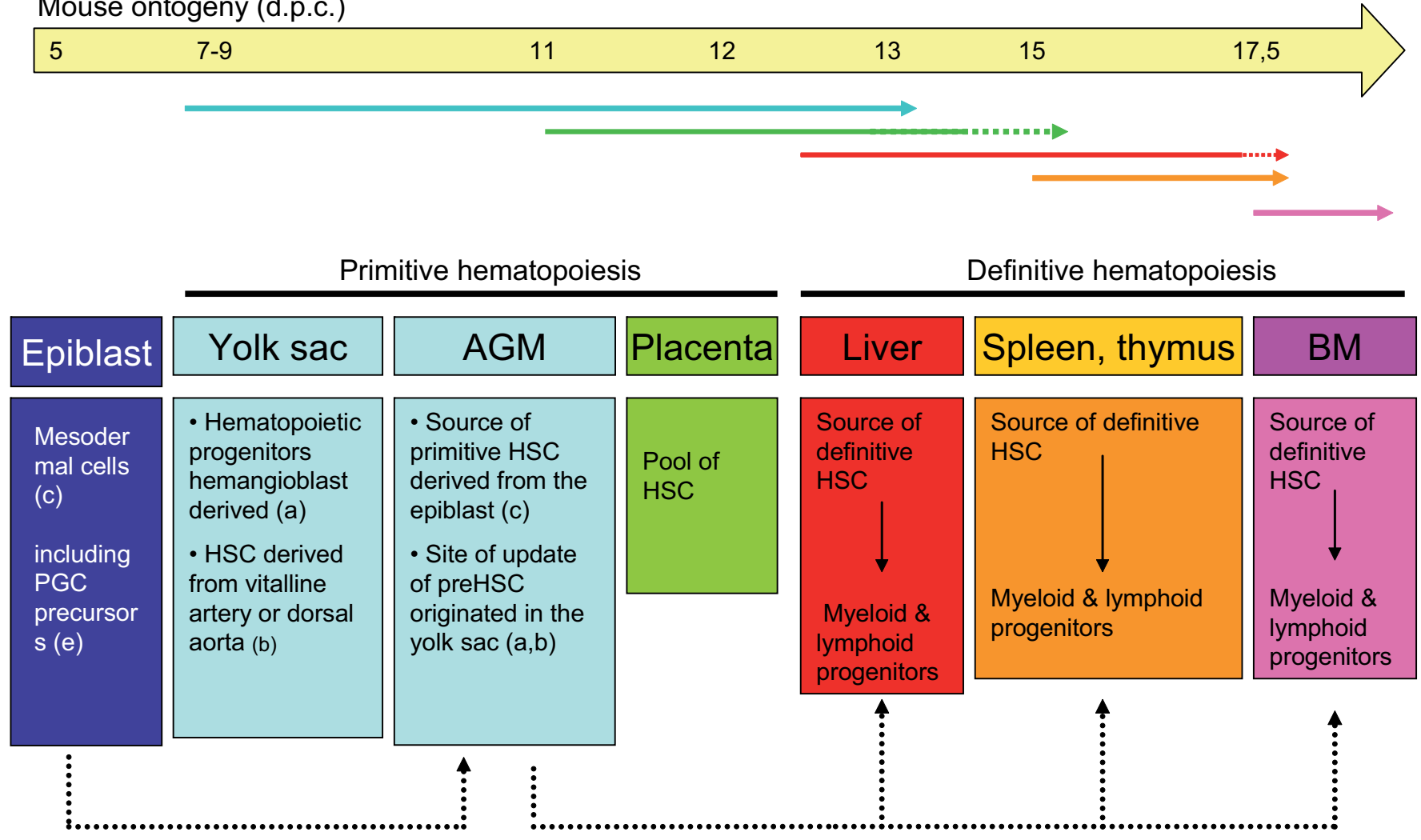

Fig. 3. Diagram of the ontogeny of hematopoietic stem cells. Different letters show distinct hypotheses. Dotted arrows represent alternative migration pathways. 
This mechanism of erasure of methylation of somatic imprinted genes protects the developing organism from the possibility of teratoma formation. However, it will affect some aspects of the pluripotentiality of these cells (e.g., potential of these cells to contribute to blastocyst development or teratoma formation after transplantation into immunodeficient mice). Interestingly, as demonstrated experimentally, EpiSC are also pluripotent but do not retain germ lineage potential (Tesar et al., 2007).

\section{From AGM to embryonic and adult hematopoiesis}

Hematopoietic stem cells (HSCs) play an indispensable role in the maintenance of blood cell homeostasis by their life-long selfrenewal activity and multipotent differentiation potential into all classes of hematopoietic cells (Kondo et al., 2003). In adult mice, and conserved through all vertebrates, hematopoiesis occurs mainly in the bone marrow. However, during ontogeny in mouse fetuses the site of hematopoiesis is modified several times (Cumano et al., 2001). A first wave of hematopoiesis is observed in the yolk sac and the AGM region at 7-9 dpc, lasting until $13 \mathrm{dpc}$ (Moore and Metcalf, 1970; Kikuchi \& Kondo, 2006). HSC activity is also detected in the placenta after $11 \mathrm{dpc}$ (Gekas et al., 2005). A second wave of hematopoiesis starts in the fetal liver at $12 \mathrm{dpc}$ and then moves towards the spleen, and later to the BM (for a review see McGrath \& Palis, 2008).

Respect to HSC migration during ontogenesis, there are sev- eral hypotheses. In the embryo, the first blood cells originate from the epiblast after gastrulation, although they do not appear as such until 7-9 dpc in the mouse embryo (Fig. 3). The mesodermal cells of the embryo will contribute in part to the extraembryonary structures, including the corion, the amnios and the yolk sac, (Fig. 1). In particular, the yolk sac derives from the mesoderm and the primitive endoderm. In the embryonic mesoderm, some structures named "blood islands" develop, consisting in erythroid cells and surrounding endothelial cells, which are formed in the vascular plexus of the yolk sac. The emergence of erythroid and endothelial precursors at the same location and at the same time suggests that they share the same ontogenetic origin, the hemangioblast (Fig. 3, hypothesis a, for a review see McGrath \& Palis, 2008). However, the relationship between these progenitors and embryonic HSCs has not been sufficiently demonstrated, and there is still some controversy with regard to the yolk sac being a source of HSCs. The main data arguing against the yolk sac as the source of HSCs come from explant culture studies, which show that early yolk sac explants do not have the potential to generate adult reconstituting HSCs or lymphoid progeny (Cumano etal., 2001). An alternative theory is that, yolk sac HSCs could be derived from the vitelline artery or upper dorsal aorta, which are upstream of the yolk sac in the circulation (Fig. 3, hypothesis b, De Bruijn et al., 2002).

Multiple studies have documented that the AGM region is a source of definitive HSCs (Medvinsky \& Dzierzak, 1996; De Bruijn

\section{FETAL DEVELOPMENT}

ADULT

\begin{tabular}{|l|l|l|l|}
\hline \multicolumn{2}{|c|}{ Birth } \\
\hline early & intermediate & late & \\
\hline
\end{tabular}
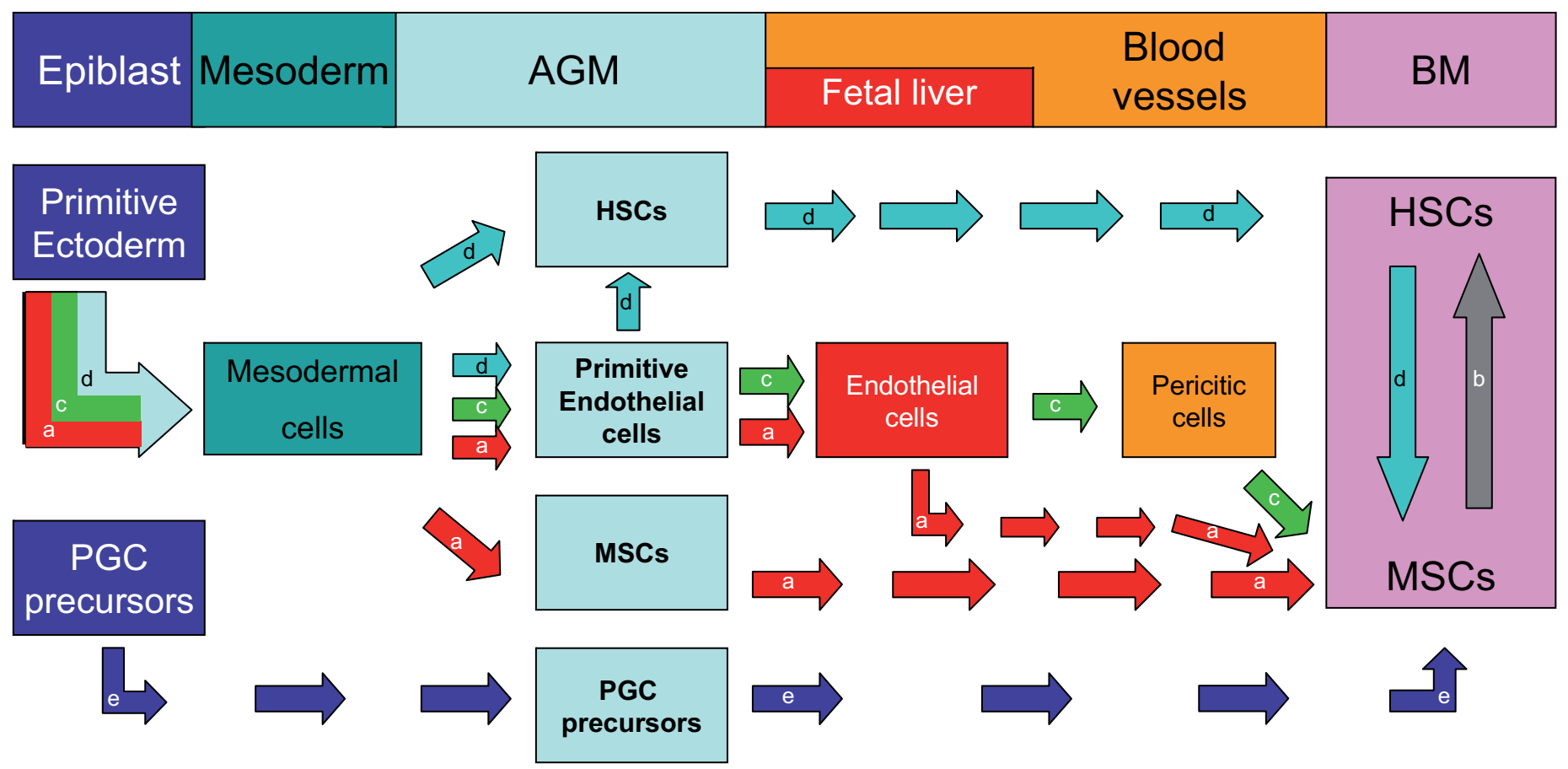

Fig. 4. Diagram of the ontogeny of mesenchymal stem cells. Different arrows colors and letters show distinct hypotheses. 
et al., 2002). Within this region, HSCs are thought to arise from hemangioblast precursors located in the ventral wall of the dorsal aorta. The study by Samokhvalov et al., (2007) demonstrated the migration of hematopoietic progenitors from the yolk sac to the umbilical cord, the AGM region and subsequently the embryonic liver and thymus. This raises the possibility that some HSCs associated with major embryonic vasculature are derived from yolk sac precursors. It is conceivable that yolk sac-derived pre HSCs acquire functional HSC characteristics in the AGM/umbilical artery and umbilical vein region (Samokhvalov et al., 2007). The AGM region could be the site of an "update" of HSC towards their new adult environment (Samokhvalov et al., 2007). Alternatively, the AGM could be a source of HSC deriving from the epiblast (Fig. 3, hypothesis c). Using a genetic tracing strategy, a recent study (Zovein et al., 2008) has demonstrated that at least mouse HSCs originate at the AGM region exclusively from endothelial precursors, excluding the possibility of an origin from the adjacent mesenchyme. These cells do migrate in the circulation towards the fetal liver and then to the bone marrow. At both sites they expand and undergo multilineage hematopoietic differentiation.

In addition, the discovery of murine placenta harboring a large pool of multipotent progenitors and HSCs during midgestation indicates that the placenta may also play an important role in the establishment of HSCs (Fig. 3, hypothesis d, Alvarez-Silva et al., 2003). It remains controversial whether these cells come from the allantoic mesoderm or originate from the $A G M$ as the main vascular route by which blood cells from the dorsal aorta circulate into the fetal liver through the umbilical vessels and the placenta (Mikkola \& Orkin, 2006).

Definitive hematopoiesis is better known, and most scientific groups agree in that involves the AGM-HSCs colonization of the fetal liver, thymus, spleen, and ultimately the bone marrow. Hematopoiesis is detected in the fetal mouse liver at $12 \mathrm{dpc}$ and in the spleen at $15 \mathrm{dpc}$ (Kikuchi \& Kondo, 2006). Until $17.5 \mathrm{dpc}$, HSC activity is not detected in BM (Christensen et al., 2004), and from then on, BM hematopoiesis is sustained throughout the life of an animal, while the rest of the tissues are no longer hematopoietic (Fig. 3). In definitive hematopoiesis, HSCs give rise to myeloid progenitors and lymphoid progenitors in all tissues where it is established, that is, in the liver, spleen, thymus and bone marrow (Fig. 3).

Recently, differentiation experiments from PGCs to HSCs (Rich, 1995) and the presence of a small subpopulation of SSEA4, Oct4 and Nanog positive cells (markers typical of PGCs) in the adult BM, which are capable of differentiating into HSC (Kucia et al., 2006a) suggest that these cells are the embryonic and adult HSC precursors that originate from a common precursor of PGCs and HSC derived from the epiblast. In the case of HSCs they will migrate to the AGM and then astray towards the hematopoietic organs (Fig. 3, hypothesis e).

\section{From AGM to BM-MSC}

The bone marrow is a well-known source of adult stem cells, providing not only hematopoietic stem cells but also nonhematopoietic stem cells located in the stroma, known as mesenchymal stem cells (MSCs). MSCs support hematopoiesis and are able to differentiate towards the mesodermal lineage to generate osteoblasts, condrocytes and adipocytes, all of them cellular types present in the adult bone marrow (Friedenstein et al., 1970; Dennis et al., 1999). MSCs are a heterogeneous population with several subgroups of cells with different proliferative and differentiation potentials.

Friedenstein et al. (1970) was the first group to isolate this type of cells by means of their ability to adhere to culture plastic, obtaining a heterogeneous population comprising both hematopoietic progenitor cells as well as nonhematopoietic stromal cells. Several groups have tried to find a specific marker that allows identification and isolation of the mesenchymal stem cells from the rest of the BM population. Stro-1, an antibody recognizing a surface antigen of unknown function, has been used to isolate clonogenic stromal cells (Gronthos et al., 1994). Unfortunately, Stro- 1 is also present, at low levels, in endothelial or pericytic cells (Bianco \& Cossu, 1999). Another group has postulated that the human MSCs can be isolated based on the expression of CD49a, the $\alpha 1$ - integrin subunit of the very late antigen-1, a receptor for collagen and laminin (Deschaseaux et al., 2003). This population CD49a high $C D 45^{\text {med/low }}$ contains all CFU-fibroblast progenitors present in the bone marrow (Deschaseaux etal., 2003). However, this population is also heterogeneous and contains many hematopoietic cells, which are CD45 ${ }^{\text {med }}$, whereas the CD45 low would identify the CFU-F or MSC (Anjos-Afonso \& Bonnet, 2007). Finally, SSEA-1 in mice (Anjos-Afonso \& Bonnet, 2007) and SSEA-4 in humans (Gang et al., 2007) have also been proposed to identify the adult mesenchymal stem cells in the BM.

MSCs origin remains uncertain, although there are different hypotheses raised throughout the last decades. All of them agree in that the epiblast will give rise to the AGM region cells that originate the mesothelial cells that are the embryonic precursors of HSC, endothelial cells and MSC that at the end will home at the bone marrow (Fig. 4). Little is known about the path these cells follow from the AGM region into the adult bone marrow. The most accepted hypothesis states that mesenchymal cells probably follow endothelial cells from the AGM region towards the ventral embryonic aorta, where differentiated endothelial cells will begin to form the blood vessels. These vessels will invade the regions meant to develop into the long bones, carrying the cells that will be forming the primitive cartilage and also the mesenchymal cells that will form the bone marrow stroma (Pardanaud et al., 1996, Fig. 4 hypothesis a). The experiments published by Anjos-Afonso \& Bonnet (2007) suggest that transdifferentiation would occur from MSCs to HSCs in the BM (Fig. 4 hypothesis b), based on experiments showing that after depletion of CD45+ cells in the bone marrow stromal fraction and transplantation of these MSC cells in mice with medullar aplasia, new CD45 hematopoietic-like cells are detected in the bone marrow. Although these results are not conclusive, as the CD45+ population could have colonized the marrow coming from other parts of the body, they suggest the possibility that a common precursor of HSC and MSC is present in the adult BM.

Another theory embraced by several authors suggests the possibility that among these differentiated endothelial cells that are in the ventral zone of the aorta, there are specialized vascular cells called pericytes that at the end would give rise to the MSCs in the bone marrow. This hypothesis is supported by the fact that the expression of Stro-1 occurs in both cellular types, pericytes and MSCs (Bianco \& Cossu, 1999, Fig. 4 hypothesis c). Other 
authors (Lakshmipathy \& Verfaille, 2005) propose the occurrence of transdifferentiation of the HSCs in the bone marrow into MSCs (Fig. 4 hypothesis d), although experiments of Wagers et al. (2002), Murry et al., (2004) and Gang et al., (2007) suggest that this hypothesis is not correct.

Lastly, Kucia and colleagues (2006b) proposed a different pattern of migration: in the AGM region, PGC, hematopoietic and mesenchymal stem cells would have a common precursor that would travel to where hematopoiesis first appears, the fetal liver, and later to the bone marrow (Fig. 4 hypothesis e). The recent discovery of VSEL (very small embryonic-like) stem cells in the adult bone marrow expressing SSEA-4 and Oct4 and which respond to SDF-1 gradient, supports this idea (Kucia et al., 2006a; Gang et al., 2007). In addition, the fact that PGC-like alkaline positive cells in the human embryo are a heterogeneous population comprising a small subpopulation of Oct-4 positive cells (Kerr et al., 2008) further supports this hypothesis.

\section{Embryonic origin of mesenchymal cells in adult tis- sues}

In addition to ES, EC, EG cells, epiblast and PGCs as stated above, several groups have identified SSEA positive cells in other tissues.

As described earlier, bone marrow contains a population of SSEA+ Oct-4+, Nanog+ stem cells that express markers of pluripotent stem cells (Kucia et al., 2006a; Gang et al., 2007). Kucia et al. named these cells very small embryonic-like (VSEL) stem cells. As mentioned before, it is hypothesized that they are deposited early in development in marrow tissue and are descendants of epiblast-derived stem cells (EpiSC) and perhaps some primordial germ cells (Kucia et al., 2006b).

Several populations of cells that express early $\mathbf{A}$ embryonic stem cell markers have been identified in bone marrow and cord blood (CB). These populations of cells could be different names for the same population of stem cells (Ratajczak et al., 2007), or pluripotent cells in different stages:

\section{VSEL Stem cells}

These cells are CXCR4+, Oct-4t, SSEA-1+, Sca-1+, Lin-, CD45- (Kucia et al., 2006a and Fig. 5). Generally, VSEL are believed to be a dormant quiescent population of PSC that resides in BM and that actively contribute to long-term hematopoiesis and turnover of other tissue specific (monopotent) stem cells located in peripheral niches, which after being mobilized into peripheral blood during organ injury, may contribute to tissue organ regeneration. As these cells are associated with MSC in the bone marrow, several authors hypothesize that the unexpected plasticity of MSC

Fig. 5. FACS analysis of adult mouse bone marrow derived mesenchymal stem cells using CD45 and SSEA antibodies. (A) Negative control. (B) SSEA positive cells isolated are shown in green (R2). Note that this population is different from the CD45+ one exposed in red (R1). with fibroblastic morphology is actually due to VSEL stem cell contamination (Anjos-Afonso \& Bonnet, 2007; Ratajczak et al., 2007). Furthermore, a single-cell-derived population was capable of differentiating abundantly into different mesenchymal cell types in vivo (Anjos-Afonso \& Bonnet, 2007). Since isolated VSEL express several markers of primordial germ cells (fetal-type alkaline phosphatase, Oct-4, SSEA-1, CXCR4, Mvh, Stella, Fragilis, Nobox, Hdac68, Kucia et al. (2006b) hypothesized that VSEL are related to a population of early PGCs. VSEL derivation would then mimic the derivation of EG cells from PGCs.

\section{Mesenchymal stromal cells}

It has also been reported that when cultured in serum-free, bFGF-containing medium, fibroblastoid mesenchymal stromal cells obtained by plating cells from BM into culture flasks and selecting plastic-adherent cells, enhance the expression of the embryonic markers SSEA-4, Oct-4 and Nanog, and give rise to multilineage differentiation (Battula et al., 2007 and Fig. 6). Another article shows however that human first-trimester fetal blood, liver, and bone marrow MSC but not adult MSC express the pluripotency stem cell markers Oct-4, Nanog, Rex-1, SSEA-3, SSEA-4, Tra-160, and Tra-1-81 (Guillot et al., 2007). The relationship of these undifferentiated MSC to other populations of Oct-4+ cells in bone marrow, including VSEL, is not known.

\section{MAPC cells}

Jiang et al. (2002) reported that MAPC cells (multipotent adult progenitor cells) obtained from bone marrow, can differentiate, at the single cell level, not only into mesenchymal cells, but also into cells with visceral mesoderm, neuroectoderm and endoderm characteristics in vitro. When injected into an early blastocyst, single

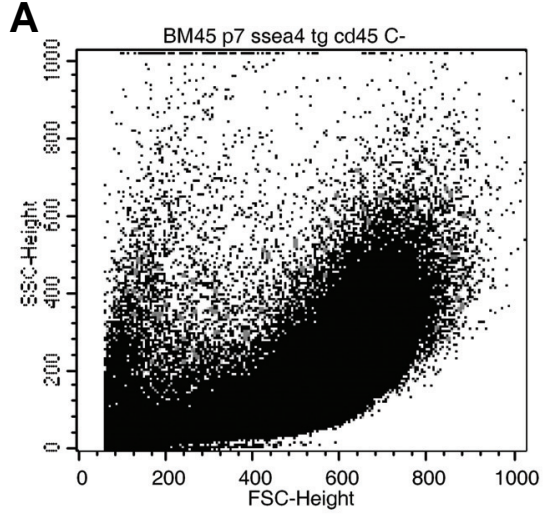

B
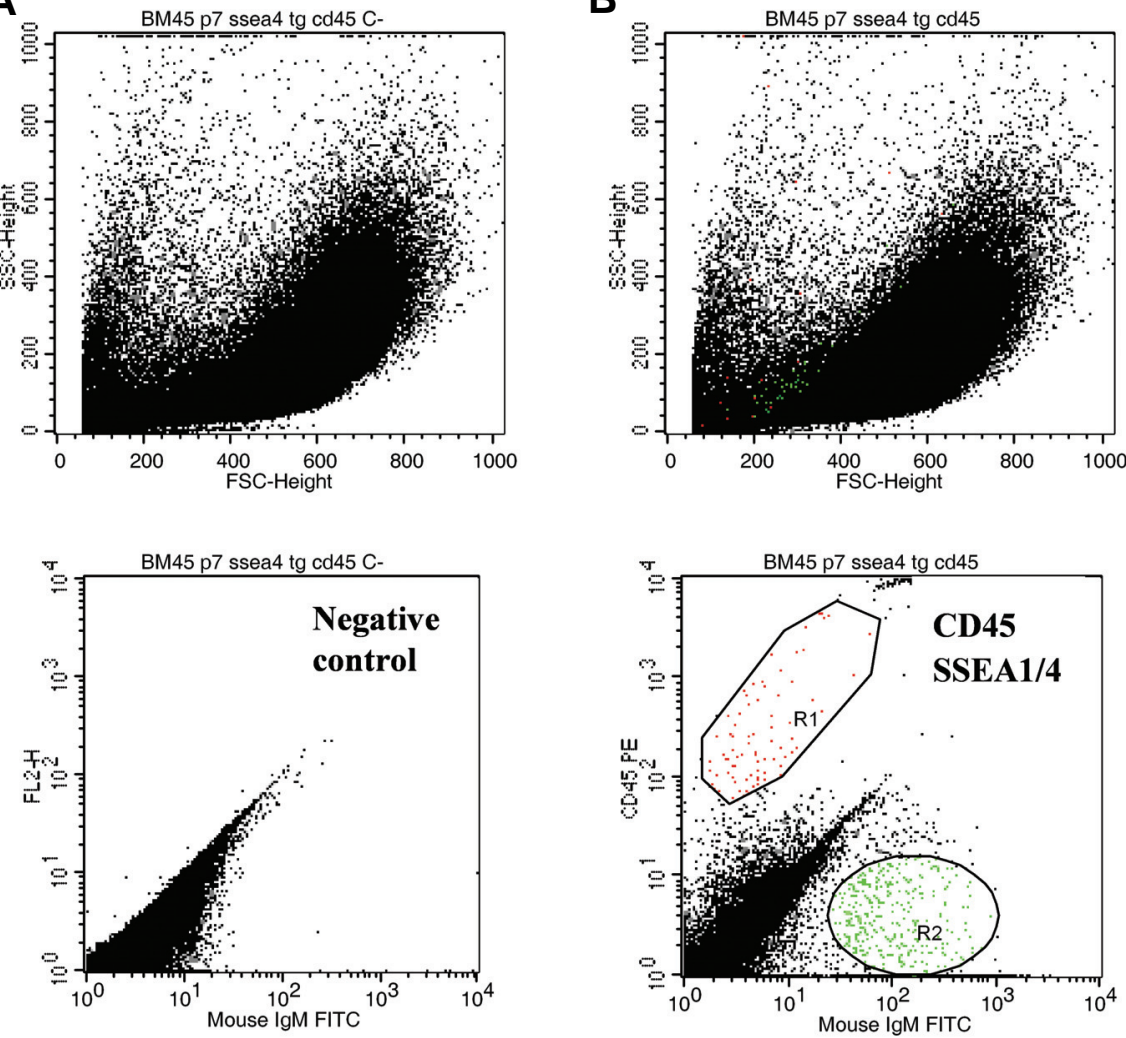

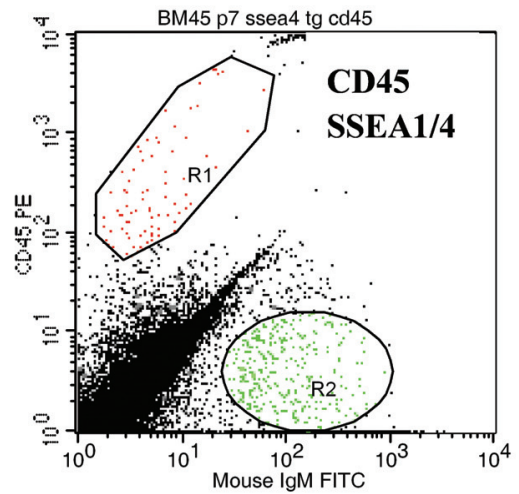



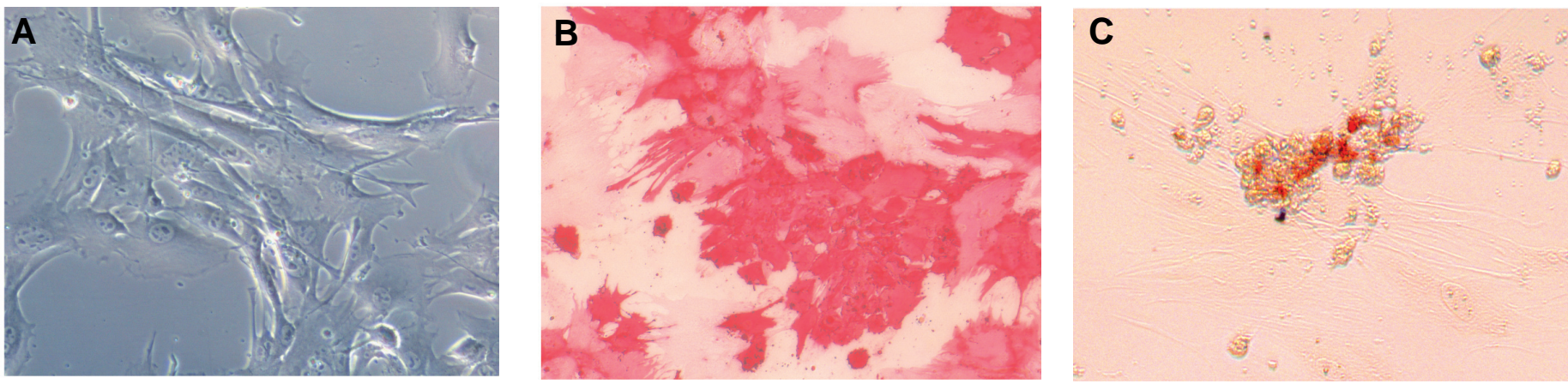

Fig. 6. Mouse bone marrow derived mesenchymal stem cells (MSC) in culture. (A) Undifferentiated MSCs seen under phase contrast optics. 200x. (B) Osteogenic lineage cells derived in culture from bone marrow derived mesenchymal stem cells after two weeks in osteogenic-inducing medium, assessed by alkaline phosphatase staining. 100x. (C) Adipogenic lineage cells derived in culture from bone marrow derived mesenchymal stem cells after two weeks in adipogenic-inducing medium, assessed by Oil red staining. 200x.

MAPCs contribute to most, if not all, somatic cell types (Jiang et al., 2002).

\section{Miami Cells}

Marrow-isolated adult multilineage inducible (MIAMI) cells, are capable of differentiating in vitrointo mature-like cells from all three germ layers. Low $\mathrm{pO}_{2}$ upregulated mRNAs for Oct-4, Rex-1, telomerase reverse transcriptase, and hypoxia-inducible factor-1 alpha, and increased the expression of SSEA-4 compared to normal $\mathrm{O}_{2}$ concentration. It is speculated that primitive MIAMI cells self-renew while localized to areas of low $\mathrm{pO}_{2}$ in the bone marrow, but tend to differentiate toward osteoblasts when they are located closer to blood vessels and exposed to higher $\mathrm{pO}_{2}$ (D' Ippolito etal., 2006).

\section{Umbilical and neonatal cord blood SSEA positive cells}

The presence of Oct-4+, Nanog+, and SSEA-3/4+ stem cells in human cord blood and umbilical cord matrix has been described (Carlin et al., 2006). Recently another group purified small cells resembling a population of murine BM-derived VSEL from human CB. These CB-isolated VSEL are very small $(3-5 \mu \mathrm{m})$ and highly enriched in a population of CXCR4+AC133+CD34+Lin-CD45mononuclear cells, and they possess relatively large nuclei containing unorganized euchromatin, express nuclear embryonic transcription factors Oct-4 and Nanog and surface embryonic antigen SSEA-4 (Kucia et al., 2007). Further studies are needed to determine whether human CB-isolated VSEL, like their murine BMderived counterparts, are endowed with pluripotency.

\section{Placenta-derived multipotent cells}

Placenta-derived multipotent cells (PDMCs) exhibit many markers common to mesenchymal stem cells (including CD105/endoglin/ $\mathrm{SH}-2, \mathrm{SH}-3$, and SH-4) and they lack hematopoietic, endothelial, and trophoblastic-specific cell markers. In addition, PDMCs exhibit ES surface markers SSEA-4, TRA-1-61, and TRA-1-80 (Yen et al., 2005). When cultured in appropriate conditions, adipogenic, osteogenic, neurogenic and hepatic differentiations were achieved (Yen et al., 2005).

\section{SSEA cells in non-hematopoietic organs}

Several groups of investigators have described the presence of Oct-4+, Nanog+, and SSEA-3/4+ stem cells in nonhematopoietic organs, such as epidermis (Dyce et al., 2006), bronchial epithelium (Kim et al., 2005), pancreas, (Kruse et al., 2006), testis (KanatsuShinohara etal., 2004), retina (Koso et al., 2006), amniotic fluid (De Coppi et al., 2007), bulge region of hair follicles (Yu et al., 2006), renal tubular epithelium (Sagrinati et al., 2006), heart (MendezFerrer et al., 2006), human fetal liver (Dan et al., 2006), and dental pulp (Kerkis et al., 2006). The expression of these embryonic stem cell markers suggests that these cells could belong to the population of embryonic/epiblast derived or PGC stem cells that may be deposited early on during development in various organs.

It is possible that other stem cells not committed to becoming PGC cells, founder cells, subsequently move through the primitive streak and give rise to several extra-embryonic mesodermal lineages and to germ cells. The presence of SSEA positive cells in the MSC population of different organs supports the hypothesis that during early development epiblast/germ line-derived cells including PGC become a founder population of pluripotent stem cells (Kucia et al., 2006b). These cells may be then deposited during embryogenesis in various organs and may persist in these locations into adulthood (for example in bone marrow) (Zambidis et al., 2006). One of these organs may be the aorta-gonadmesonephros. Furthermore, there is some additional evidence that some epiblast derived PGC themselves might go astray and seed to peripheral tissues during migration through the embryo proper on their way to the genital ridges (Upadhyay \& Zamboni, 1982).

A similar hypothesis goes even further, and states that PGC may go astray from the main migration stream and become deposited in various tissues (Francavilla and Zamboni, 1985). On the way to the genital ridges $C X C R 4+P G C$ cells migrate through the embryo proper through the AGM region. Like PGC, HSC are also CXCR4+ and their migration is regulated by $S D F-1$ gradient, which becomes expressed during the second trimester of gestation in the fetal liver (Medvinsky and Dzierzak, 1996). The translocation from the liver to the BM is again mediated by the SDF-1 gradient, which becomes expressed in developing BM tissue (Ara etal., 2003). In addition to HSC, the fetal liver may also chemoattract some migrating PGC in a $S D F-1$ dependent manner. Furthermore, it had even been suggested that PGC gives rise in AGM to a population of definitive HSC (Rich, 1995).

Interestingly, PGCs can give rise to cells of the hematopoietic system such as the hematopoietic stem cells cobblestone-area forming cell, and cells of the erythroid lineage (Rich, 1995). The 
possibility of epiblast cells deposition in various tissues during embryonic life is also supported by the fact that oocytes were generated by putative germ cells of the BM and peripheral blood in sterilized female mice (Johnson et al., 2005). Male germ cells have also been derived from bone-marrow cells (Nayernia et al., 2006).

\section{Summary and Conclusions}

We have reviewed the ontogeny and specification of the epiblast derived cells towards various stem cell compartments, both in vitroand in vivo. Data is presented supporting the hypothesis that pluripotent SSEA+ stem cells, isolated from both embryonal and adult tissues are descendants of epiblast derived cells that could be deposited during embryonic life in various tissues. A great deal of controversy and further basic and preclinical research is needed to elucidate how the different types of stem cells are specified during the mammalian embryonic life.

From a Cell Therapy point of view, the question remains, whether these pluripotent stem cells are only developmental remnants from the epiblast or if they can continuously contribute in adult life to the renewal of other more committed adult stem cells.

More importantly, the presence of pluripotent stem cells in adult tissues opens the possibility of aiming at the development of techniques that will allow for their reactivation in various organs in order to regenerate them without the need for stem cell transplantation, providing a whole new path for human Cell Therapy.

\section{Acknowledgements}

This work was supported in part by grants PI-308 from the "Fondo de Investigaciones Sanitarias", Ministry of Health, Spain, SAF2005-05662 and SAF2008-03837 from the Ministry of Science and Innovation, Spain and from the Foundation Mutua Madrileña, Spain. The authors wish to acknowledge Predes García for mouse bone marrow isolation teaching, Fatima Dominguez for excellent technical assistance, Fernando Nuñez for veterinary help, and Juliette Siegfried for linguistic assistance.

\section{References}

ALVAREZ-SILVA, M., BELO-DIABANGOUAYA, P., SALAUN, J. and DIETERLENLIEVRE, F. (2003). Mouse placenta is a major hematopoietic organ. Development. 130: 5437-5444.

ANJOS-AFONSO, F. and BONNET, D. (2007). Nonhematopoietic/endothelial SSEA-1+ cells define the most primitive progenitors in the adult murine bone marrow mesenchymal compartment. Blood. 109(3): 1298-1306.

ARA, T., TOKOYODA, K., SUGIYAMA, T., EGAWA, T., KAWABATA, K. and NAGASAWA, T. (2003). Long-term hematopoietic stem cells require stromal cell-derived factor-1 for colonizing bone marrow during ontogeny. Immunity. 19(2): 257-267.

BATTULA, V.L., BAREISS, P.M., TREML, S., CONRAD, S., ALBERT, I., HOJAK, S., ABELE, H., SCHEWE, B., JUST, L., SKUTELLA, T. and RING, H.J. (2007). Human placenta and bone marrow derived MSC cultured in serum-free, b-FGFcontaining medium express cell surface frizzled- 9 and SSEA- 4 and give rise to multilineage differentiation. Differentiation. 75(4): 279-291.

BOIANI, M. and SCHOLER, H.R. (2005). Regulatory networks in embryo-derived pluripotent stem cells. Nature Rev Mol Cell Biol. 6(11): 872-884.

BIANCO, P. and COSSU, G. (1999). Uno, nessuno e centomila: searching for the identity of mesodermal progenitors. Expt Cell Res 251:257-263

BRIMBLE, S.N., SHERRER, E.S., UHL, E.W., WANG, E., KELLY, S., MERRILL, A.H. J.R., ROBINS, A.J. and SCHULZ, T.C. (2007). The cell surface glycosphingolipids SSEA-3 and SSEA-4 are not essential for human ESC pluripotency. Stem Cells. 25(1): 54-62.

BRINSTER, R.L. (1974). The effect of cells transferred into the mouse blastocyst on subsequent development. J Exp Med. 140(4): 1049-1056.

BRONS, I.G.M., SMITHERS L.E., TROTTER, M.W.B., RUGG-GUNN, P., SUN, B., LOPES, S.M.C.S., LOPES, HOWLETT S.K., CLARKSON, A., AHRLUNDRICHTER L., PEDERSEN R.A., VALLIER, L. (2007) Derivation of pluripotent epblast stem cells from mammalian embryos. Nature 448:191-196.

BUEHR, M. and SMITH, A. (2003). Genesis of embryonic stem cells. Philos Trans $R$ Soc Lond B Biol Sci. 358(1436): 1397-402.

CARLIN, R., DAVIS, D., WEISS, M., SCHULTZ, B., and TROYER, D. (2006). Expression of early transcription factors Oct4, Sox2 and Nanog by porcine umbilical cord (PUC) matrix cells. Reprod Biol Endocrinol. 4(1): 8.

CHOU, Y.F., CHEN, H.H., EIJPE, M., YABUUCHI, A., CHENOWETH, J.G., TESAR, P., LU, J., MCKAY, R.D., and GEIJSEN N. (2008). The growth factor environment defines distinct pluripotent ground states in novel blastocyst-derived stem cells. Cell. 135(3): 449-61.

CHRISTENSEN, J.L., WRIGHT, D.E., WAGERS, A.J. and WEISSMAN, I.L. (2004) Circulation and chemotaxis of fetal hematopoietic stem cells. PLOS Biology. 2(3):E75.

CLARK, A.T., BODNAR, M.S., FOX, M., RODRIQUEZ, R., ABEYTA, M.J., FIRPO, M.T. and PERA, R.A. (2004). Spontaneous differentiation of germ cells from human embryonic stem cells in vitro. Hum Mol Genet. 13: 727-739.

CUMANO, A., FERRAZ, J. C., KLAINE, M., DI SANTO, J. P. and GODIN, I. (2001). Intraembryonic, but not yolk sac hematopoietic precursors, isolated before circulation, provide long-term multilineage reconstitution. Immunity. 15: 477485.

DAN, Y.Y., RIEHLE, K.J., LAZARO, C., TEOH, N., HAQUE, J., CAMPBELL, J.S., and FAUSTO, N. (2006). Isolation of multipotent progenitor cells from human fetal liver capable of differentiating into liver and mesenchymal lineages. Proc Natl Acad Sci USA. 103(26): 9912-9917.

DE BRUIJN, M. F., MA, X., ROBIN, C., OTTERSBACH, K., SANCHEZ, M. J. and DZIERZAK, E. (2002). Hematopoietic stem cells localize to the endothelial cell layer in the midgestation mouse aorta. Immunity. 16: 673-683.

DE COPPI, P., BARTSCH, G.J.R., SIDDIQUI, M.M., XU, T., SANTOS, C.C., PERIN, L., MOSTOSLAVSKY, G., SERRE, A.C., SNYDER, E.Y., YOO, J.J., FURTH, ME., SOKER, S., and ATALA, A. (2007). Isolation of amniotic stem cell lines with potential for therapy. Nature Biotechnol. 25(1): 100-106.

DE MIGUEL, M.P., and DONOVAN, P.J. (2000). Isolation and Culture of Mouse Germ Cells. Methods in Molecular Biology, Vol. 137, Developmental Biology Protocols, Vol. III. Tuan RS, Lo CW (eds). Humana Press Inc. Totowa, NJ. 38 : 403-408.

DE MIGUEL, M.P., FEDERSPIEL, M.J. and DONOVAN, P.J. (2000). Regulation of Growth and Survival in the Mammalian Germline. From Stem Cell to Sperm Function. Goldberg E (ed). Serono Symposium. Springer-Verlag, New York, NY. 6: 55-70.

DENNIS JE, MERRIAM A, AWADALLAH A, YOO JU, JOHNSTONE B, CAPLAN AI (1999). A quadripotential mesenchymal progenitor cell isolated from the marrow of an adult mouse. J Bone Miner Res. 14(5):700-9.

DESCHASEAUX, F., GINDRAUX, F., SAADI, R., OBERT, L., CHALMERS, D. HERVE, P. (2003). Direct selection of human bone marrow mesenchymal stem cells using an anti-CD49a antibody reveals their CD45med,low phenotype. $\mathrm{Br}$ $J$ Haematol. 122(3):506-17.

D'IPPOLITO, G., DIABIRA, S., HOWARD, G.A., ROOS, B.A. and SCHILLER, P.C (2006). Low oxygen tension inhibits osteogenic differentiation and enhances stemness of human MIAMI cells. Bone. 39(3): 513-522.

DONOVAN, P.J., and DE MIGUEL, M.P. (2003). Turning Germ Cells into Stem Cells. Current Opinion in Genetics \& Development. 13: 463-471.

DONOVAN, P.J., and DE MIGUEL, M.P. (2005). Gonocyte Development and Differentiation. Sertoli Cell Biology. Skinner MK, Griswold MD (eds). Elsevier, San Diego, CA. 22: 417-435.

DYCE, P.W., WEN, L. and LI, J. (2006). In vitro germline potential of stem cells derived from fetal porcine skin. Nature Cell Biology. 8: 384-390.

EVANS, M.J. and KAUFMAN, M.H. (1981). Establishment in culture of pluripotentia cells from mouse embryos. Nature. 292: 154-156.

FRANCAVILLA, S. and ZAMBONI, L. (1985). Differentiation of mouse ectopic 
germinal cells in intra- and perigonadal locations. J Exp Zool. 233: 101-109.

FRIEDENSTEIN, A.J., CHAILAKHJAN, R.K., LALYKINA, K.S. (1970). The development of fibroblast colonies in monolayer cultures of guinea-pig bone marrow and spleen cells. Cell Tissue Kinet. 4:393-403.

GANG, E.J., BOSNAKOVSKI, D., FIGUEIREDO, C.A., VISSER, J.W. and PERLINGEIRO, R.C. (2007). SSEA-4 identifies mesenchymal stem cells from bone marrow. Blood. 109(4): 1743-1751.

GEIJSEN, N., HOROSCHAK, M., KIM, K., GRIBNAU, J., EGGAN, K. and DALEY, G.Q. (2004). Derivation of embryonic germ cells and male gametes from embryonic stem cells. Nature. 427: 148-154.

GEKAS, C., DIETERLEN-LIEVRE, F., ORKIN, S.H. and MIKKOLA, H.K. (2005). The placenta is a niche for hematopoietic stem cells. Dev Cell. 8(3): 365-375.

GINSBURG, M., SNOW, M. H. L. and McLAREN, A. (1990). Primordial germ cells in the mouse embryo during gastrulation. Development. 110: 521-529.

GRONTHOS, S., GRAVES, S.E., OHTA, S. and SIMMONS, P.J. (1994). The Stro$1+$ fraction of adult human bone marrow contains the osteogenic precursors. Blood. 84: 4164-4173.

GUAN, K., NAYERNIA, K., MAIER, L.S., WAGNER, S., DRESSEL, R., LEE, J.H., NOLTE, J., WOLF, F., LI, M., ENGEL, W. and HASENFUSS, G. (2006). Pluripotency of spermatogonial stem cells from adult mouse testis. Nature, 440(7088):1199-203.

GUILLOT, P.V., GOTHERSTROM, C., CHAN, J., KURATA, H. and FISK, N.M. (2007). Human first-trimester fetal MSC express pluripotency markers and grow faster and have longer telomeres than adult MSC. Stem Cells. 25(3): 646-654.

HAY, D.C., SUTHERLAND, L., CLARK, J. and BURDON, T. (2004). Oct-4 knockdown induces similar patterns of endoderm and trophoblast differentiation markers in human and mouse embryonic stem cells. Stem Cells. 22(2): 225235.

HENDERSON, J.K., DRAPER, J.S., BAILLIE, H.S., FISHEL, S., THOMSON, J.A., MOORE, H. and ANDREWS, P.W. (2002). Preimplantation human embryos and embryonic stem cells show comparable expression of stage-specific embryonic antigens. Stem Cells. 20: 329-337.

HUBNER, K., FUHRMANN, G., CHRISTENSON, L., KEHLER, J., REINBOLD, R., DE LA FUENTE, R., WOOD, J., STRAUSS, J.F., $3^{\text {RD }}$, BOIANI, M. and SCHOLER, H.R. (2003). Derivation of oocytes from mouse embryonic stem cells. Science. 300: 1251-1256.

JIANG, Y., JAHAGIRDAR, B.N., REINHARDT, R.L., SCHWARTZ, R.E., KEENE, C.D., ORTIZ-GONZALEZ, X.R., REYES, M., LENVIK, T., LUND, T., BLACKSTAD, M., DU, J., ALDRICH, S., LISBERG, A., LOW, W.C., LARGAESPADA, D.A. and VERFAILLIE, C.M. (2002). Pluripotency of mesenchymal stem cells derived from adult marrow. Nature. 418(6893): 41-49.

JOHNSON, J., BAGLEY, J., SKAZNIK-WIKIEL, M., LEE, H.J., ADAMS, G.B., NIIKURA, Y., TSCHUDY, K.S., TILLY, J.C., CORTES, M.L., FORKERT, R., SPITZER, T., IACOMINI, J., SCADDEN, D.T. and TILLY, J.L. (2005). Oocyte generation in adult mammalian ovaries by putative germ cells in bone marrow and peripheral blood. Cell. 122: 303-315

KANATSU-SHINOHARA, M., INOUE, K., LEE, J., YOSHIMOTO, M., OGONUKI, N., MIKI, H., BABA, S., KATO, T., KAZUKI, Y., TOYOKUNI, S., TOYOSHIMA, M., NIWA, O., OSHIMURA, M., HEIKE, T., NAKAHATA, T., ISHINO, F., OGURA, A., and SHINOHARA, T. (2004). Generation of pluripotent stem cells from neonatal mouse testis. Cell. 119(7): 1001-1012.

KERKIS, I., KERKIS, A., DOZORTSEV, D., STUKART-PARSONS, G.C., GOMES MASSIRONI, S.M., PEREIRA, L.V., CAPLAN, A.I. and CERRUTI, H.F. (2006). Isolation and characterization of a population of immature dental pulp stem cells expressing OCT-4 and other embryonic stem cell markers. Cells Tissues Organs. 184(3-4): 105-116.

KERR, CL, HILL, C.M., BLUMENTHAL, P.D., GEARHART, J.D. (2008). Expression of pluripotent stem cell markers in the human fetal testis. Stem Cel/s. 2008 26(2):412-21 .

KIKUCHI, K. and KONDO, M. (2006). Developmental switch of mouse hematopoietic stem cells from fetal to adult type occurs in bone marrow after birth. ProcNat/ Acad Sci USA. 103(47): 17852-17857.

KIM, C.F., JACKSON, E.L., WOOLFENDEN, A.E., LAWRENCE, S., BABAR, I., VOGEL, S., CROWLEY, D., BRONSON, R.T. and JACKS, T. (2005). Identification of bronchioalveolar stem cells in normal lung and lung cancer. Cell. 121: 823-835
KINDER, S.J., TSANG, T.E.,QUINLAN, G.A., HADJANTONAKIS, A-K., NAGY, A and TAM, P.P.L. (1999). The orderly allocation of mesodermal cells to the extraembryonic structures and the anteroposterior axis during gastrulation of the mouse embryo. Development. 126: 4691-4701.

KONDO, M., WAGERS, A.J., MANZ, M.G., PROHASKA, S.S., SCHERER, D.C., BEILHACK, G.F., SHIZURU, J.A. and WEISSMAN IL. (2003). Biology of hematopoietic stem cells and progenitors: implications for clinical application. Annu Rev Immunology. 21: 759-806.

KOSO, H., OUCHI, Y., TABATA, Y., AOKI, Y., SATOH, S., ARAI, K. and WATANABE, S. (2006). SSEA-1 marks regionally restricted immature subpopulations of embryonic retinal progenitor cells that are regulated by the Wnt signaling pathway. Dev. Biol. 292(1): 265-276.

KRUSE, C., KAJAHN, J., PETSCHNIK, A.E., MAASS, A., KLINK, E., RAPOPORT, D.H., and WEDEL, T. (2006). Adult pancreatic stem/progenitor cells spontaneously differentiate in vitro into multiple cell lineages and form teratoma-like structures. Ann Anat. 188(6): 503-517.

KUCIA, M., RECA, R., CAMPBELL, F.R., ZUBA-SURMA, E., MAJKA, M., RATAJCZAK, J., and RATAJCZAK, M.Z. (2006a). A population of very small embryonic-like (VSEL) CXCR4(+)SSEA-1(+)Oct-4+ stem cells identified in adult bone marrow. Leukemia. 20(5): 857-869.

KUCIA, M., ZUBA-SURMA, E., WYSOCZYNSKI, M., DOBROWOSKA, H., RECA, R. RATAJCZAK, J. and RATAJCZAK, M.Z. (2006b). Physiological and pathological consequences of identification of very small embryonic like (VSEL) stem cells in adult bone marrow. J Physiol Pharmacol. 57(5): 5-18.

KUCIA, M., HALASA, M., WYSOCZYNSKI, M., BASKIEWICZ-MASIUK, M., MOLDENHAWER, S., ZUBA-SURMA, E., CZAJKA, R., WOJAKOWSKI, W., MACHALINSKI, B., and RATAJCZAK, M.Z. (2007). Morphological and molecular characterization of novel population of CXCR4+ SSEA-4+ Oct-4+ very small embryonic-like cells purified from human cord blood: preliminary report. Leukemia. 21(2):297-303.

KURIMOTO, K., YABUTA, Y., OHINATA, Y., SHIGETA, M., YAMANAKA, K. and SAITOU, M. (2008). Complex genome-wide transcription dynamics orchestrated by Blimp1 for the specification of the germ cell lineage in mice. Genes Dev. 22 (12): 1617-35.

LAKSHMIPATHY, U., and VERFAILLE, C. (2005). Stem cell plasticity. Blood Rev. 19(1):29-38.

LAWSON, K.A., MENESE, J.J. and PEDERSON, R.A. (1991). Clonal analysis of epiblast fate during germ layer formation in the mouse. Development. 113: 891 913.

LEE, J., INOUE, K., ONO, R., OGONUKI, N., KOHDA, T., KANEKO-ISHINO, T., OGURA, A. and ISHINO, F. (2002). Erasing genomic imprinting memory in mouse clone embryos produced from day 11.5 primordial germ cells. Development. 129: 1807-1817.

MANN, J.R. (2001). Imprinting in the germ line. Stem Cells. 19: 287-294.

MATSUI, Y., ZSEBO, K. and HOGAN, B.L. (1992). Derivation of pluripotential embryonic stem cells from murine primordial germ cells in culture. Cell. 70: 841847.

MCGRATH, K. and PALIS, J. (2008). Ontogeny of erythropoiesis in the Mammalian embryo. Curr Top Dev Biol. 82:1-22.

MCLAREN, A. (2003). Primordial germ cells in the mouse. Dev Biol. 262: 1-15.

MEDVINSKY, A. and DZIERZAK, E. (1996). Definitive hematopoiesis is autonomously initiated by the AGM region. Cell. 86: 897-906.

MENDEZ-FERRER, S., PRAT, S., LUCKIC, A. ET AL. (2006). ES-Like cells in the adult murine heart. $4^{\text {th }}$ ISSCR annual meeting, p.62.

MIKKOLA, H.K. and ORKIN, S.H. (2006). The journey of developing hematopoietic stem cells. Development. 133(19): 3733-3744.

MOLYNEAUX, K. and WYLIE, C. (2004). Primordial germ cell migration. Int J Dev Biol. 48: 537-544.

MOORE, M.A. and METCALF, D. (1970). Ontogeny of the haemopoietic system: yolk sac origin of in vivo and in vitro colony forming cells in the developing mouse embryo. Br J Haematol. 18(3): 279-296.

MURRY, C.E., SOONPAA, M.H., REINECKE, H., NAKAJIMA, H., NAKAJIMA, H.O., RUBART, M., PASUMARTHI, K.B., VIRAG, J.I., BARTELMEZ, S.H., POPPA, V., BRADFORD, G., DOWELL, J.D., WILLIAMS, D.A. and FIELD, L.J. (2004). Haematopoietic stem cells do not transdifferentiate into cardiac myocytes in myocardial infarcts. Nature 428(6983):664-8. 
MURAMATSU, T. and MURAMATSU, H. (2004). Carbohydrate antigens expressed on stem cells and early embryonic cells. Glycoconj J. 21(1-2): 41-45.

NAYERNIA, K., LEE, J.H., DRUSENHEIMER, N., NOLTE, J., WULF, G., DRESSEL, R., GROMOL, J. and ENGEL, W. (2006). Derivation of male germ cells from bone marrow stem cells. Lab Invest. 86: 654-663.

OOSTERHUIS, J.W. and LOOIJENGA, L.H. (2005). Testicular germ-cell tumors in a broader perspective. Nat. Rev. Cancer. 5: 210-222.

PARDANAUD, L., LUTON, D., PRIGENT, M., BOURCHEIX, L.M., CATALA, M. and DIETERIN-LIEVRE, F. (1996). Two distinct endothelial lineages in ontogeny, one of them related to hematopoiesis. Development. 122: 1363-1371.

PESCE, M., WANG, X., WOLGEMUTH, D.J. and SCHOLER, H. (1998). Differential expression of the Oct-4 transcription factor during mouse germ call development. Mech. Develop. 71: 89-98.

QUINLAN, G.A., WILLIAMS, E.A., TAN, S-S. and TAM, P.P.L. (1995). Neuroectodermal fate of epiblast cells in the distal region of the mouse egg cylinder: Implication for body plan organization during early embryogenesis. Development. 121: 87-98.

RATAJCZAK, M.Z., MACHALINSKI, B., WOJAKOWSKI, W., RATAJCZAK, J. and KUCIA, M. (2007). A hypothesis for an embryonic origin of pluripotent Oct-4(+) stem cells in adult bone marrow and other tissues. Leukemia. 21(5): 860-867.

RESNICK, J.L., BIXLER, L.S., CHENG, L., and DONOVAN, P.J. (1992).Long-term proliferation of mouse primordial germ cells in culture. Nature 359(6395): 5501.

RICH, IN. (1995). Primordial germ cells are capable of producing cells of the hematopoietic system in vitro. Blood. 86: 463-472.

ROSSANT, J., CHAZAUD, C. and YAMANAKA, Y. (2003). Lineage allocation and asymmetries in the early mouse embryo. Philos. Trans. R. Soc. Lond. B Biol Science. 358: 1341-1349.

ROSSANT, J. and MCBURNEY, M.W. (1982). The development potential of a euploid male teratocarcinoma cell line after blastocyst injection. J Embryol Exp Morphol. 70: 99-112.

ROSSANT, J. and PAPAIOANNOU, V.E. (1984). The relationship between embryonic, embryonal carcinoma and embryo-derived stem cells. Cel/ Diff. 15: 155161.

SAGRINATI, C., NETTI, G.S., MAZZINGHI, B., LAZZERI, E., LIOTTA, F., FROSALI, F., RONCONI, E., MEINI, C., GACCI, M., SQUECCO, R., CARINI, M., GESUALDO, L., FRANCINI, F., MAGGI, E., ANNUNZIATO, F., LASAGNI, L., SERIO, M., ROMAGNANI, S. and ROMAGNANI, P. (2006). Isolation and charaterization of multipotent progenitor cells from the Bowman's capsule of adult human kidneys. J Am Soc Nephrol. 17: 2443-2456.

SAITOU, M., BARTON, S.C. and SURANI, M.A. (2002). A molecular programme for the specification of germ cell fate in mice. Nature. 418: 293-300

SAMOKHVALOV, I.M., SAMOKHVALOVA, N.I. and NISHIKAWA, S. (2007). Cell tracing shows the contribution of the yolk sac to adult haematopoiesis. Nature. 446(7139):1056-61.

SHAMBLOTT, M.J., AXELMAN, J., WANG, S., BUGG, E.M., LITTLEFIELD, J.W., DONOVAN, P.J., BLUMENTHAL, P.D., HUGGINS, G.R. and GEARHART, J.D. (1998). Derivation of pluripotent stem cells from cultured human primordial germ cells. Proc Nat/ Acad Sci USA. 95(23): 13726-31.

SOLTER, D., DOMINIS, M. and DAMJANOV, I. (1981). Embryo-derived teratocar- cinoma. III. Development of tumors from teratocarcinoma-permissive and nonpermissive strain embryos transplanted to $\mathrm{F} 1$ hybrids. Int J Cancer. 28: 479 483.

STEVENS, L.C. (1970). The development of transplantable teratocarcinomas from intratesticular grafts of pre-and post-implantation mouse embryos. Dev Biol.21: 364.

TAM, P.P.L. and ZHOU, S.X. (1996). The allocation of epiblast cells to ectodermal and germ-line lineages is influenced by the position of cells in the gastrulating mouse embryo. Dev Biol. 178: 124-132.

TESAR P.J., CHENOWETH J.G., BROOK, F.A., DAVIES T.J., EVANS, E.P., MACK, D.L., GRADNER, R.L., MCKAY, R.D.G. (2007). New cell lines from mouse epiblast share defining feautres with human embryonic stem cells. Nature 448:196-202

TOYOOKA, Y., TSUNEKAWA, N., TAKAHASHI, Y., MATSUI, Y., SATOH, M. and NOCE, T. (2000). Expression and intracellular localization of mouse Vasahomologue protein during germ cell development. Mech Development. 93(1-2): 139-149.

TSANG, T.E., KHOO, P-L., JAMIESON, R. V., ZHOU, S.X., ANG, S-L., BEHRINGER, R. and TAM, P P.L. (2001). The allocation and differentiation of mouse primordial germ cells. Int J Dev Biol. 45: 549-55

UPADHYAY, S., and ZAMBONI, L. (1982). Ectopic germ cells: natural model for the study of germ cell sexual differentiation. Proc Nat/Acad Sci USA. 79(21):6584 6588 .

WAGERS, A.J, SHERWOOD, R.I., CHRISTENSEN, J.L. and WEISSMAN, I.L. (2002). Little evidence for developmental plasticity of adult hematopoietic stem cells. Science 297(5590):2256-9.

WYLIE, C. (1999). Germ cells. Cell. 96(2): 165-174.

YABUTA, Y., KURIMOTO, K., OHINATA, Y., SEKI, Y. and SAITOU M. (2006). Gene expression dynamics during germline specification in mice identified by quantitative single-cell gene expression profiling. Biol Reprod. 75(5): 705-716.

YAMAZAKI, Y., MANN, M.R., LEE, S.S., MARCH, J., MCCARREY, J.R., YANAGIMACHI, R., and BARTOLOMEI, M.S. (2003). Reprogramming of primordial germ cells begins before migration into the genital ridge, making these cells inadequate donors for reproductive cloning. Proc Nat/ Acad Sci USA. 100 12207-12212.

YEN, B.L., HUANG, H.I., CHIEN, C.C., JUI, H.Y., KO, B.S., YAO, M., SHUN, C.T. YEN, M.L., LEE, M.C. and CHEN, Y.C. (2005). Isolation of multipotent cells from human term placenta. Stem Cells. 23(1): 3-9.

YU, H., FANG, D., KUMAR, S.M., LI, L., NGUYEN, T.K., ACS, G., HERLYN, M. and $\mathrm{XU}, \mathrm{X}$. (2006). Isolation of a novel population of multipotent adult stem cells from human hair follicles. Am J Pathol. 168: 1879-1888.

ZAMBIDIS, E.T., OBERLIN, E., TAVIAN, M., and PEAULT, B. (2006). Bloodforming endothelium in human ontogeny: lessons from in utero development and embryonic stem cell culture. Trends Cardiovasc Med. 16(3): 95-101.

ZOVEIN, A.C., HOFMANN, J.J., LYNCH, M., FRENCH, W.J., TURLO, K.A., YANG, Y., BECKER, M.S., ZANETTA, L., DEJANAM E., GASSON, J.C., TALLQUIST, M.D., and IRUELA-ARISPE, M.L. (2008). Fate tracing reveals the endothelial origin of hematopoietic stem cells. Cell Stem Cell. 3(6): 625-36.

ZWAKA, T.P. and THOMSON, J.A. (2005). A germ cell origin of embryonic stem cells? Development. 132: 227-233. 


\section{Further Related Reading, published previously in the Int. J. Dev. Biol.}

See our recent Special Issue Fertilization, in honor of David L. Garbers and edited by Paul M. Wassarman and Victor D. Vacquier at: http://www.ijdb.ehu.es/web/contents. php?vol=52\&issue=5-6

Foetal germ cells: striking the balance between pluripotency and differentiation

Patrick Western

Int. J. Dev. Biol. (2009) 53: 393-409

From bone marrow to therapeutic applications: different behaviour and genetic/epigenetic stability during mesenchymal stem cell expansion in autologous and foetal bovine sera?

Gaetana A. Tonti and Ferdinando Mannello

Int. J. Dev. Biol. (2008) 52: 1023-1032

Prolonged human/sheep cellular chimerism following transplantation of human hemopoietic stem cells into the ewe celomic cavity Monica Michelini, Sandra Papini, Alfredo Rosellini, Giuseppe Noia, Maria S. Ligato, Salvatore Mancuso, Andrea Cavazzana, Gloria Bertacca, Claudio Di Cristofano, Riccardo Saccardi, Serena Urbani and Roberto P. Revoltella Int. J. Dev. Biol. (2008) 52: 365-370

Genetic and epigenetic instability of human bone marrow mesenchymal stem cells expanded in autologous serum or fetal bovine serum

John-Arne Dahl, Shivali Duggal, Neralie Coulston, Douglas Millar, John Melki, Aboulghassem Shahdadfar, Jan E. Brinchmann and Philippe Collas

Int. J. Dev. Biol. (2008) 52: 1033-1042

Characterization of fibroblast-like cells from the rat olfactory bulb

Masoud Soleimani, Samad Nadri, Mohammad Salehi, Aligholi Sobhani and Athena Hajarizadeh. Int. J. Dev. Biol. (2008) 52: 979-984

An efficient method for isolation of murine bone marrow mesenchymal stem cells Samad Nadri, Masoud Soleimani, Reza H. HosSeni, Mohammad Massumi, Amir Atashi and Reza Izadpanah. Int. J. Dev. Biol. (2007) 51: 723-729

August Rauber (1841-1917): from the primitive streak to Cellularmechanik Sabine Brauckmann

Int. J. Dev. Biol. (2006) 50: 439-449

Vertebrate somitogenesis: a novel paradigm for animal segmentation?

Olivier Pourquié

Int. J. Dev. Biol. (2003) 47: 597-603

Developmental potential of mouse tetraploid cells in diploid <--> tetraploid chimeric embryos.

Yuji Goto, Junko Matsui and Nobuo Takagi

Int. J. Dev. Biol. (2002) 46: 741-745

The allocation and differentiation of mouse primordial germ cells.

T E Tsang, P L Khoo, R V Jamieson, S X Zhou, S L Ang, R Behringer and P P Tam

Int. J. Dev. Biol. (2001) 45: 549-555

The role of Otx2 in organizing the anterior patterning in mouse.

A Simeone and D Acampora

Int. J. Dev. Biol. (2001) 45: 337-345

Role of the anterior visceral endoderm in restricting posterior signals in the mouse embryo.

A Perea-Gomez, M Rhinn and S L Ang

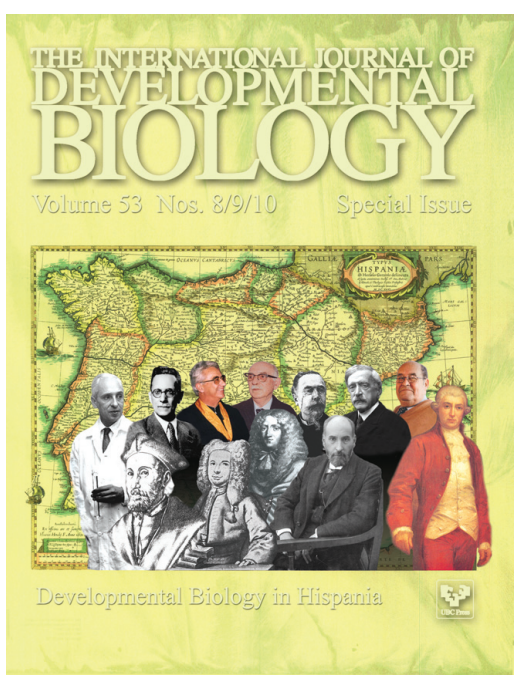

5 yr ISI Impact Factor $(2008)=3.271$

Int. J. Dev. Biol. (2001) 45: 311-320

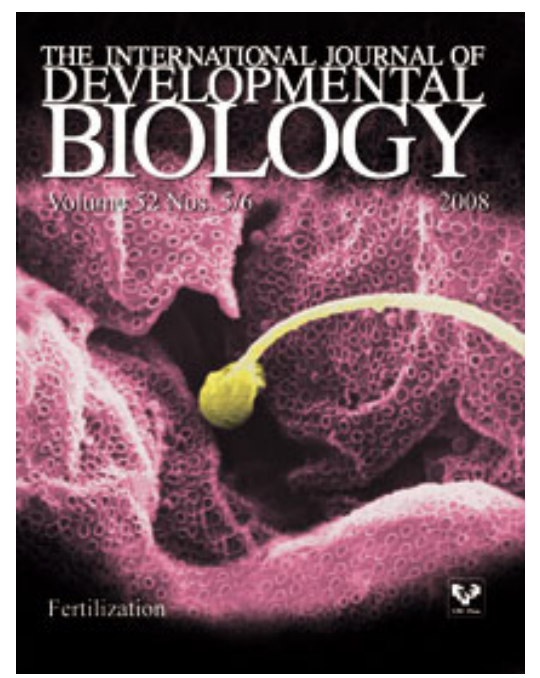

